\title{
Rural employment trends in Brazil: an analysis using dynamic panel models
}

\author{
Evânio Mascarenhas Paulo, Francisco José Silva Tabosa,
} Ahmad Saeed Khan and Leonardo Andrade Rocha

\begin{abstract}
This article considers certain dimensions of the quality of employment in Brazil, particularly in rural zones. It starts from the perception of changes in rural production relations and the repercussions these have on employment practices. A panel data methodology is applied to capture the determinants of job quality, and a quality of employment index is proposed. Rural employment is more precarious than its urban counterpart, although the differences have been diminishing over time. In the agriculture sector, the economic growth of the 2000 decade merely resulted in the existing conditions of employment being extended to new contracts, without any change in average quality. Rising labour income and education levels are important not only for enhancing the quality of employment but also as a strategy for overcoming problems such as heterogeneity between groups.
\end{abstract}

\section{Keywords}

Rural employment, labour market, rural areas, labour relations, working conditions, measurement, evaluation, employment statistics, econometric models, Brazil

\section{JEL classification}

$$
\text { C23, J43, R11 }
$$

\section{Authors}

Evânio Mascarenhas Paulo is a Professor in the Department of Economics at Universidade Regional do Cariri, Brazil. Email: evanio.paulo@urca.br.

Francisco José Silva Tabosa is a Professor on the Graduate Programme in Rural Economics in the Department of Agricultural Economics at the Federal University of Ceará, Brazil. Email: franzetabosa@ufc.br.

Ahmad Saeed Khan is a Professor on the Graduate Programme in Rural Economics in the Department of Agricultural Economics at the Federal University of Ceará, Brazil. Email: saeed@ufc.br.

Leonardo Andrade Rocha is a Professor in the Department of Human Sciences at Universidade Federal Rural do Semi-Árido (Brazil). Email: leonardoandrocha@ yahoo.com.br. 


\section{Introduction}

The processes that have unfolded in the rural and agricultural domain in recent years are of such complexity and scale that they have permeated a variety of structures specific to these spaces. In addition to specifically rural phenomena, such as the mechanization and modernization of agriculture, other changes associated with the urban sector, such as the semi-lethargic state of industrial activities, have had a major impact on the rural sector (Da Silva, 1997).

In this context, the structures that make up Brazil's agricultural and rural systems are likely to experience drastic and dramatic change. This article addresses one of these structures in particular: the labour market. This market can be expected to act as a mirror of the changes in production systems and techniques that have occurred in agriculture and the rural domain in recent years (Carneiro, 1998).

The new production processes that are starting to be applied in agriculture (which are more aligned with modern capitalist accumulation techniques) will naturally change hiring practices and the number of workers needed to operate the means of production in agriculture (Campolina, Silveira and De Magalhães, 2009). The specialist literature sees the additional labour force that is released as a result of changes in agricultural processes, but not absorbed by industrial and service activities in the urban area, as an immediate consequence of these new phenomena in the rural labour market. Thus, the spatial movement of workers from the countryside to the city is a likely consequence of these processes. However, in the most recent period, the rural exodus that characterized previous decades has not ended but been reformulated. This can be discerned in a significant reduction in direct migrations from the countryside to the city and an equally significant increase in "sectoral migrations" from agricultural to non-agricultural employment, with a set of elements stimulating these movements (Balsadi, 2007).

The factors that motivate rural dwellers to migrate to the cities are diminishing; and this represents an important turning point in the relationship between the rural and urban zones $\backslash$. However, differences in income and general employment conditions between the traditional primary sector and other sectors of the economy are stimulating migration between sectors. Thus, the impact and influence of non-agricultural activities on the rural labour market have steadily increased. Nowadays, workers do not need to abandon the spatial environment of their homes in rural areas, but increasingly engage in off-farm activities that are not inherent to agriculture, but nonetheless associated with it (Balsadi and Da Silva, 2008).

Accordingly, this article makes a general analysis of the elements of employment quality that are prevalent among rural and urban wage earners in Brazil, considering the new determinants of the rural space and their consequences for employment practices in the countryside. In particular, it reviews recent changes in the rural labour market, focusing on the effects of the transformations that have taken place in rural spaces, and gauging the quality of rural and urban jobs in Brazil through the quality of employment index. Lastly, the article uses the panel data model to identify the factors that affect the quality of these jobs for wage-earners in Brazil.

As this study requires a detailed database that is continuous through time, it mainly draws on secondary information from databases held by national research institutes, in particular the Brazilian Institute of Geography and Statistics (IBGE).

This article is divided into five sections, including this introduction. Section II presents the methods and study strategies, and discusses conceptual and methodological issues. Section III discusses the descriptive results of the employment quality index, and section IV analyses the empirical results obtained from the econometric models proposed. The final section offers concluding remarks on the research. 


\section{Conceptual and methodological issues}

\section{Database and construction of the quality of employment index}

The data used in the study were taken from the National Household Sample Survey (PNAD) spanning 2004-2014. This period saw the consolidation of several changes in the world of employment and is therefore important for analysing the recent Brazilian labour market, particularly rural employment. The decade of 2000 provides the scenario for phenomena such as the growth of the labour force and rising average labour income. These transformations are the result of a "metamorphosis" of hiring and recruitment practices, and of an increase in demand for a more highly skilled and trained work force that elicits a process of competition, both between employers and between employees, each with their respective effects on job quality.

This study aims to identify the factors that influence job quality for four specific population groups. The first represents urban agricultural wage-earning employees, that is individuals employed as wage-earners (both formal and informal) in agriculture sector enterprises but living in urban areas. The second group consists of urban non-agricultural workers, who are wage earners in non-agricultural enterprises living in urban regions. The third group is comprised of wage earners engaged in agricultural activities who live in rural areas; and, lastly, the fourth group corresponds to rural employees in non-agricultural enterprises.

This study only considers wage-earning employment, because the nature and characteristics of this type of employment (formality, working hours, security, among others) are more amenable to analysis than other types. While this allows for a better characterization of this segment of the labour market, the different segments have unique characteristics and, thus, different job quality dynamics. Moreover, the different segmentation patterns in job quality affect each other mutually, as the quality of wage-earning employment both influences and is influenced by the other segments of the labour market.

Job quality partly reflects the environment and employment opportunities that manifest themselves differently and produce very heterogeneous quality standards in the different segments of the labour market. Thus, a change in the composition of the labour market, such as a larger or smaller share of wage-earning employment, has effects on job quality generally. This can also induce processes that influence the quality of the different labour market segments, including wage labour itself. The terminology of job quality developed in this paper does not capture these interactions in labour market segmentation dynamics.

According to Do Nascimento and others (2008), the concept of employment quality may vary across different dimensions. However, the purpose of this research is to use labour market variables to measure the effects of specific elements that the authors consider relevant for determining the quality of employment. These include the absence of child labour, regular weekly working hours without being overworked, the employment contract, contribution to public or private social security institutes and the level of income, in addition to issues related to the workers' education level. However, job quality involves factors that are difficult to address, such as exposure to health and other risks, and supervision of working conditions by the labour inspectorate system, among others. This also needs to be taken into account when working with regionalized data.

The employment quality index proposed in this paper is an adaptation of the index initially formulated by Balsadi (2007), which is used as the initial matrix. The employment quality index is based on a scoring system, in which each subcategory band of the index is assigned a value ranging from 0 (worst condition) to 4 (best). Table 1 gives details on how the indices are constructed. 
Table 1

Quality of employment index: construction methodology

\begin{tabular}{|c|c|c|c|c|c|}
\hline $\begin{array}{l}\text { Schooling } \\
{[0.20]}\end{array}$ & $\begin{array}{l}\text { [0] No education } \\
\text { or primary } \\
\text { education only, with } \\
\text { subsistence wage }\end{array}$ & $\begin{array}{l}\text { [1] Previous case } \\
\text { without restriction }\end{array}$ & $\begin{array}{l}\text { [2] Primary to } \\
\text { secondary education }\end{array}$ & $\begin{array}{l}\text { [3] Higher and } \\
\text { postgraduate } \\
\text { education }\end{array}$ & $\begin{array}{l}\text { [4] Previous case } \\
\text { with high wage }\end{array}$ \\
\hline $\begin{array}{l}\text { Working hours } \\
\text { per week } \\
{[0.15]}\end{array}$ & $\begin{array}{l}{[0] \text { More than }} \\
44 \text { hours }\end{array}$ & [1] 40-44 hours & [2] 30-39 hours & [3] 1-29 hours & $\begin{array}{l}\text { [4] Previous case } \\
\text { with high wage }\end{array}$ \\
\hline $\begin{array}{l}\text { Worker's age } \\
{[0.23]}\end{array}$ & $\begin{array}{l}\text { [0] From 0-15 } \\
\text { years of age } \\
\text { (child labour) }\end{array}$ & $\begin{array}{l}\text { [1] 16-18 } \\
\text { years of age }\end{array}$ & $\begin{array}{l}\text { [2] 19-24 years } \\
\text { old, with low } \\
\text { education level and } \\
\text { informal schooling }\end{array}$ & $\begin{array}{l}\text { [3] Previous case } \\
\text { without restriction }\end{array}$ & $\begin{array}{l}\text { [4] Over } 25 \\
\text { years of age }\end{array}$ \\
\hline $\begin{array}{l}\text { Remuneration } \\
{[0.30]}\end{array}$ & $\begin{array}{l}\text { [0] Below } \\
\text { minimum wage } \\
\text { (subsistence) }\end{array}$ & $\begin{array}{l}\text { [1] } 1-2 \text { times the } \\
\text { minimum wage }\end{array}$ & $\begin{array}{l}\text { [2] 2-3 times the } \\
\text { minimum wage }\end{array}$ & $\begin{array}{l}\text { [3] } 3-5 \text { times the } \\
\text { minimum wage }\end{array}$ & $\begin{array}{l}\text { [4] More than } \\
\text { five times the } \\
\text { minimum wage }\end{array}$ \\
\hline $\begin{array}{l}\text { Informal work } \\
{[0.12]}\end{array}$ & $\begin{array}{l}\text { [0] No social security } \\
\text { contribution, no } \\
\text { employment contract, } \\
\text { low income }\end{array}$ & $\begin{array}{l}\text { [1] Previous case } \\
\text { without restriction }\end{array}$ & $\begin{array}{l}\text { [2] No social security } \\
\text { contribution but with } \\
\text { employment contract }\end{array}$ & $\begin{array}{l}\text { [3] With social } \\
\text { security but no } \\
\text { employment contract }\end{array}$ & $\begin{array}{l}\text { [4] With social } \\
\text { security and } \\
\text { employment contract }\end{array}$ \\
\hline
\end{tabular}

Source: Prepared by the authors, on the basis of O. V. Balsadi, "Qualidade do emprego na agricultura brasileira no período 2001-2004 e suas diferenciações por culturas", Revista de Economia e Sociologia Rural, vol. 45, No. 2, April-June 2007.

The following sub-indices were selected: (i) the worker's level of education, blended with low income, in order to verify the relationship between poor job quality and low schooling; (ii) hours of work, which measures the different levels of hours worked and affords a perception of overwork; (iii) worker age, with a view to detecting the presence of child labour and the different levels of vulnerability to which young workers are exposed; (iv) average remuneration, since the average rate of pay affects the perception of the job quality to which workers are exposed; and (v) type of engagement, which reveals the presence of temporary and casual work, blended with low rates of pay. The quality of employment index is essentially a weighted average of these categories, which capture aspects that are relevant to the perception of job quality.

Following Do Nascimento and others (2008), the quality of employment index is obtained from the weighted average of the partial indicators. The weight of each category is specified in the first column of table 1. According to the aforementioned authors, the weight of each category in the composition of the quality of employment index reflects their relative contributions and was established through the conventional weighting system, in other words by the proposer of the index, based on a prioritization system. The weighting may generate controversy, because the importance attributed to each partial indicator always implies a degree of arbitrariness on the part of the authors. Nonetheless, the quality of employment index is constructed as the weighted averages of the partial indicators. Thus, with due allowance for arbitrariness, these indicators can contribute to an analysis of the quality of rural and urban employment, which makes it possible to assimilate the conditions of wage-earning employment in greater detail and to make comparisons between them.

\section{Description of the variables}

In order to determine job quality among the groups selected in this research, a set of variables was constructed to synthesize the factors affecting the quality pattern in employment relationships. These variables are summarized in table 2 . 
Table 2

Group of variables, description and sources

\begin{tabular}{lcl}
\hline Variables & $\begin{array}{c}\text { Code } \\
\text { of the variable }\end{array}$ & Source \\
\hline Natural logarithm of the quality of employment index & QE & Prepared by the authors \\
\hline Natural logarithm of the lagged quality of employment index & QEt-1 & Endogenous variable \\
\hline Natural logarithm of agricultural value-added & VA01 & $\begin{array}{l}\text { Brazilian Institute of Geography } \\
\text { and Statistics (IBGE) }\end{array}$ \\
\hline Natural logarithm of non-agricultural value-added & VA02 & IBGE \\
\hline $\begin{array}{l}\text { Natural logarithm of average labour income in each } \\
\text { federative unit (urban agricultural workers) }\end{array}$ & RM01 & IBGE \\
\hline $\begin{array}{l}\text { Natural logarithm of average labour income in each } \\
\text { federative unit (urban non-agricultural workers). }\end{array}$ & RM02 & IBGE \\
\hline $\begin{array}{l}\text { Natural logarithm of the average labour income in each } \\
\text { federative unit (rural non-agricultural workers) }\end{array}$ & RM03 & IBGE \\
\hline $\begin{array}{l}\text { Natural logarithm of the average labour income in each } \\
\text { federative unit (rural agricultural workers) }\end{array}$ & RM04 & IBGE \\
\hline Natural logarithm of the Gini index of the concentration of labour income & IG & Prepared by the authors \\
\hline $\begin{array}{l}\text { Natural logarithm of the share of persons who have completed } \\
\text { at least secondary education in each federative unit. }\end{array}$ & EDU & IBGE \\
\hline
\end{tabular}

Source: Prepared by the authors.

The first variable described (QE) refers to the quality of employment index, constructed as explained in the previous section. As noted above, the index gathers data on the degree of formalization of employment contracts and the pattern of workers' income. It thus indicates the sophistication of employment practices. This research seeks to verify potential differences between the employment conditions in the rural area and in agriculture, compared to the contractual relations prevailing in urban areas and in non-agricultural activities. The aim is therefore to identify their determinants and their contributions to the quality of employment.

The next variable described $\left(Q E_{t-1}\right)$ is the lagged employment quality index, which is a characteristic of the type of econometric modelling used in this research, to evaluate the properties of employment practices among the groups studied. This variable is expected to be statistically significant, since employment quality in the previous period proves to be a determinant of the quality of future employment. This expectation reflects the natural course of labour market dynamics, in which employment relations tend to become more sophisticated and advanced over time, so that -in an economic growth climate such as prevailed during the years in question - the chances of regressing to a lower standard are remote. Moreover, given the presence of labour legislation and its specific features (which set a standard for contractual relations that is starting to be applied in the market), rolling back these rights could result in the labour laws being flouted.

The variable VA01 represents agricultural value-added in each state. One possible behaviour pattern for this variable is that increased agricultural production in the states tends to enhance employment quality. The rationale for this is that the growth of crop and livestock output would increase the demand for labour, raise workers' incomes and improve employment conditions. Alternatively, the level of activity may not be associated with an increase in labour market quality. Thus, economic growth would merely entail the extension of existing contractual relationships to new hirings, without changes in their structure. The evaluation of the signs and the significance levels of the coefficients of this variable will indicate which of these hypotheses is supported more strongly.

The variable VA02, which expresses the value-added of non-agricultural activities, is expected to have a positive (negative) effect on job quality, insofar as new jobs - which in the case of non-agricultural activities are usually more complex and of higher quality than purely agricultural jobs - induce an improvement (deterioration) in the quality of employment. Moreover, as in the previous case, the variable 
in question may not be related to an increase in the quality of employment contracts because it does not involve changes in hiring practices. This study also aims to evaluate the behaviour of cross-over effects: that is, how economic growth in non-agricultural activities affects the dynamics of agricultural and rural employment; and, conversely, how the expansion of agricultural activities affects the quality of non-agricultural and urban employment.

The "RM" variables group expresses the average income level of the main job for each group in each of Brazil's federative units (states). Thus, RM01 expresses the average income level of urban agricultural workers; RM02 the average income of urban non-agricultural workers; RM03 the average income of rural non-agricultural workers and, lastly, RM04 the average income of rural agricultural workers.

The "IG" variable corresponds to the Gini index, which measures the degree of income concentration in each federative unit, thereby evaluating how the income structure is distributed. The expected negative sign is justified by the perception that, as income concentration increases, job quality tends to deteriorate. It is further assumed that, if this coefficient is insignificant, job quality is independent of the structure of income concentration in the labour market. Thus, income growth alone guarantees improvements in job quality, even if this does not imply changes in the concentration structure.

Lastly, the variable "EDU" expresses the proportion of the population of each state who have completed at least secondary education. Higher levels of schooling would be expected to imply greater efficiency; and, as the overall level of education rises, job quality can also be expected to improve.

\section{(a) Generalized method of moments (GMM)}

When evaluating the behaviour of the quality of agricultural and non-agricultural employment - both urban and rural - and its determinants, in a dynamic panel data system, the lagged dependent variable must be included as one of the explanatory variables (Baltagi, 2009). Accordingly, the estimators of the generalized method of moments for systems (system-GMM) are used, as developed in Arellano and Bond (1991), Arellano and Bover (1995) and Blundell and Bond (1998).

In brief, this research attempts to estimate models comprising the four equations specified in the following panel data regression models:

$$
\begin{aligned}
& \ln \left(Q E_{A U}\right)=\beta_{1} \ln \left(Q E_{t-1}\right)+\beta_{2} \ln (A V 01)+\beta_{3} \ln (A V 02)+\beta_{4} \ln (R M 01)+\beta_{5} \ln (I G)+\beta_{6} \ln (E D U)+V_{t}+\mu_{i t} \\
& \ln \left(Q E_{N U}\right)=\beta_{1} \ln \left(Q E_{t-1}\right)+\beta_{2} \ln (A V 01)+\beta_{3} \ln (A V 02)+\beta_{4} \ln (R M 02)+\beta_{5} \ln (I G)+\beta_{6} \ln (E D U)+V_{t}+\mu_{i t} \\
& \ln \left(Q E_{N R}\right)=\beta_{1} \ln \left(Q E_{t-1}\right)+\beta_{2} \ln (A V 01)+\beta_{3} \ln (A V 02)+\beta_{4} \ln (R M 03)+\beta_{5} \ln (I G)+\beta_{6} \ln (E D U)+V_{t}+\mu_{i t} \\
& \ln \left(Q E_{A R}\right)=\beta_{1} \ln \left(Q E_{t-1}\right)+\beta_{2} \ln (A V 01)+\beta_{3} \ln (A V 02)+\beta_{4} \ln (R M 04)+\beta_{5} \ln (I G)+\beta_{6} \ln (E D U)+V_{t}+\mu_{i t}
\end{aligned}
$$

In these equations, the dependent variable is the quality of employment (QE) index for each federative unit; and its subscripts refer to urban agricultural employment (AU), urban non-agricultural employment $(\mathrm{NU})$, rural non-agricultural employment (NR) and rural agricultural employment (AR), respectively; " $Q E_{t-1}$ " expresses the employment quality index lagged by one year, and in each case represents the lagged dependent variable for each group (the introduction of this variable is characteristic of this type of econometric modelling); "VA01" represents the agricultural value-added in each federative unit; "VA02" expresses non-agricultural value-added; "RM01" represents the average income in each state in urban agricultural activities in the first equation; "RMO2" represents the average income in urban non-agricultural activities in the second equation; "RM03" represents the average income in rural non-agricultural activities 
in the third equation; "RM04" represents the average income in rural agricultural activities in the fourth equation, "IG" expresses the degree of income concentration for each state, measured by the Gini index; "EDU" represents the proportion of people who have completed at least secondary education in each subnational unit; $V_{i}$ represents individual-specific unobservable effects, and $\mu_{i t}$ represents random disturbances. The subscripts $i$ and $t$ refer to the $\mathrm{i}$-th state in year $t$, respectively.

These models make the following assumptions: $E\left[v_{i}\right]=E\left[\mu_{i t}\right]=E\left[v_{i t} \mu_{i t}\right]=0$ for $i=1,2, \ldots, n$; $t=1,2, \ldots, t$. In addition, the error is assumed to be temporally uncorrelated; that is, $E / \mu_{i, t}, \mu_{i, s} /=0$ for $i=1,2, \ldots, n \forall t \neq s$. There is also the standard assumption regarding the initial conditions, $E\left|Q E_{t-1} \mu_{i t}\right|=0$ for $i=1,2, \ldots, n$ and $t=1,2, \ldots, t$. These assumptions are valid for all equations in the models presented above.

The studies published in the literature, especially Arellano and Bond (1991), draw attention to a number of problems when using traditional estimation techniques to estimate the models specified above, owing to the following:

(i) the presence of individual-specific unobservable effects, $V_{t}$, together with the dependent variable lagged by one period, $Q E_{t-1}$, on the right side of the equation. In this case, the omission of individual fixed effects in the dynamic panel model makes the ordinary least squares (OLS) estimators biased and inconsistent. However, the within-groups estimator, which corrects for the presence of fixed effects, generates an estimate of $\beta_{1}$ that is biased downward in panels with a short time span; and

(ii) the likely endogeneity of the explanatory variables. In this case, it is necessary to deal with endogeneity on the right side of the equations to avoid a potential bias generated by the simultaneity problem.

Marinho and Araujo (2010) state that one way to overcome this problem would be to eliminate the presence of fixed effects from the model. Thus, a first attempt would be to estimate the models by OLS with dummy variables for each state, or else using the within-groups method, which generates the same estimations as the previous method, but the coefficients have slightly smaller standard deviations. The coefficient estimators in both methods will be smaller than those obtained by OLS. However, it could still be shown that the bias in the dynamic panel persisted.

The same authors suggest another way to eliminate these problems would be to take the first difference of the equations and estimate them using the generalized method of moments (GMM). This is usually called the generalized method of moments in differences (difference-GMM) and consists of eliminating the fixed effects by taking the first difference of the equations in question. Equation (1), for example, was transformed into equation (5):

$$
\Delta \ln \left(Q E_{A U}\right)=\beta_{0}+\beta_{1} \Delta\left(\ln Q E_{t-1}\right)+\beta_{2} \Delta(\ln V A 01)+\beta_{3} \Delta(\ln V A 02)+\beta_{4} \Delta(R M 01)+\beta_{5} \Delta(I G)+\beta_{6} \Delta(E D U)+V_{t}+\mu_{i t}
$$

Thus, for any variable, $Y_{i t}, \Delta \ln Y_{i t}=\ln Y_{i t}-\ln Y_{i t-1}$. Note that in the equations above, $\Delta \ln Q E_{t-1}$ is correlated with the error terms, $\Delta \ln \mu_{i t}$. Consequently, the OLS estimators for its coefficients will be biased and inconsistent. This makes it necessary to use instrumental variables for $\triangle \ln Q E_{t-1}$ and in each model.

The assumptions adopted in the equations presented at the start of this section mean that the momentconditions $E\left[\Delta \ln Q E_{t-1} \Delta \ln \mu_{i t}\right]=0$ for $t=3,4, \ldots, n$ and $s \geq 2$ are valid. On the basis of these moments, $\ln Q E_{t-1}$, for $t=3,4, \ldots, n$ and $s \geq 2$, must be used as instruments for the equation in first difference form.

In the second case, the values of the variable lagged by one or more periods are valid instruments for estimating the equation; and, in the last case, the values lagged by two or more periods are valid instruments.

According to Arellano and Bover (1995) and Blundell and Bond (1998), these instruments are weak when the dependent and explanatory variables display strong persistence and when the relative 
variance of the fixed effects increases. This produces a biased and inconsistent difference-GMM estimator for panels covering short periods.

Consequently, Arellano and Bover (1995) and Blundell and Bond (1998) propose a system to reduce this bias problem that combines the set of difference equations - equations (1) to (4) - with the set of equations in which the variables expressed in level form -equation (5). This is referred to as system generalized method of moments (sys-MGM). For the difference equations, the set of instruments is as described above. For the regression of the level equation, the appropriate instruments are the lagged differences of the respective variables. For example, assuming that the differences of the explanatory variables are uncorrelated with the individual fixed effects (for $t=3,4, \ldots, n$ ) $E\left[\Delta \ln Q E_{t-1} \mu_{i t}\right]=0$ for $i=1,2, \ldots, n$. Then, if the explanatory variables in differences and $\Delta \ln Q E_{t-1}$ are exogenous or weakly exogenous, they constitute valid instruments for the level equation. The same is true if they are endogenous; but the instruments are the explanatory variables in differences lagged by one period and $\triangle \ln Q E_{t-1}$ considered in this article, according to Marinho and Araujo (2010).

The system-GMM estimations are the result of using a corrected estimator to prevent the respective estimator of the variances from underestimating the true variances in a finite sample. The estimator used was proposed in two steps. In the first step, the error terms are assumed to be independent and homoscedastic across states and over time. In the second step, the residuals obtained in the first step are used to construct a consistent estimate of the variance-covariance matrix, thus relaxing the independence and homoscedasticity assumptions. The second-step estimator is asymptotically more efficient than the first-step estimator (Marinho and Araujo, 2010).

Lastly, there are two tests of the robustness and consistency of the models. The Sargan test is used to verify the validity of the instruments. If the null hypothesis is not rejected, the instruments are robust. In addition, since the ite error is initially assumed not to be autocorrelated, first-order and second-order serial correlation tests are performed on the first-difference residuals, $\Delta \varepsilon_{i t}$. These errors are expected to be first-order correlated and second-order non-autocorrelated (Marinho and Araujo, 2010).

\section{Some descriptive results}

The data presented below illustrate the case of the Brazilian labour market in recent years, and reveal the expansion of non-agricultural jobs among the country's urban and rural population. This represents a major transformation of the pattern of organization of the rural domain in Brazil, driven by training processes and the growth of agribusinesses and their spread into rural areas. It also reflects the development of a new service sector dynamic; for while a large part of the population continues to live in rural areas, its main occupation is not directly related to agriculture. Another important fact that emerges from table 3 is that total rural employment increases as agricultural employment (both urban and rural) declines, thus demonstrating the sectoral migration of workers to non-agricultural activities.

Table 3

Brazil: employed population, by area of residence and type of activity, 2004 and 2014 (Number of people)

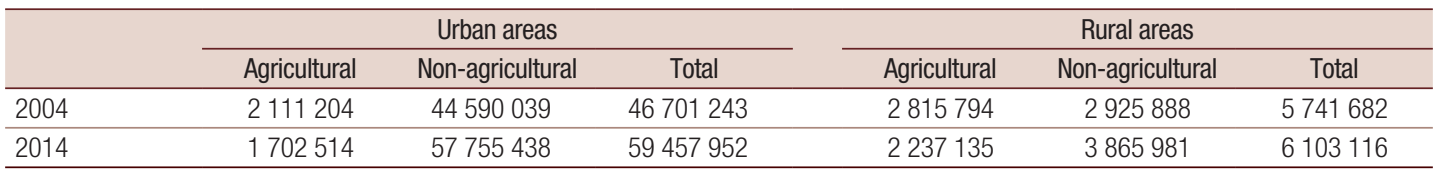

Source: Prepared by the authors, on the basis of Brazilian Institute of Geography and Statistics (IBGE), "Pesquisa Nacional por Amostra de Domicílios - PNAD" [online] https://www.ibge.gov.br/estatisticas/sociais/educacao/9127-pesquisanacional-por-amostra-de-domicilios.html?=\&t=0-que-e. 
The indices of employment quality are presented below for Brazil's subnational units. Map 1, displaying the employment quality index for rural and urban agricultural employment, shows that the best quality levels are registered in the centre-south of the country, particularly in the Centre-West Region (especially the states of Mato Grosso, Mato Grosso do Sul and Goiás). Along with São Paulo and Paraná, this region displays the best quality standards in agricultural employment, whether urban or rural. Authors such as Priori and others (2012) add that, until recently, many regional economies in Brazil have tended to pursue the rationale of the external market, rather than coordinating mutually in a national production territory. The case of Brazilian agriculture, in which the modern agricultural complex of the centre-south part of the country bears little or no relation to subsistence farming in the interior of the North-East Region or in the rural communities of Amazônia (where quality standards are lower), does not seem to be far removed from this contemporary Brazilian reality. Obviously, this has repercussions on standards of job quality, as can be seen in map 1.

As noted by Dos Passos, Bariou and Dubreuil (2006), the investments made mainly in the 1970s enabled the Brazilian agricultural frontier to expand towards the South and Centre-West Regions, with significant agricultural productivity growth. As a result, these regions came to play an important role in the Brazilian economy, consolidating a successful agro-export model. The modernization of agricultural activities in these regions raised productivity levels considerably, which, in conjunction with the level of urbanization of these regions, enabled the development of a production complex aligned with agribusiness interests. In terms of job quality, this system offers much better conditions of agricultural employment than in other Brazilian regions, as can be seen in map 1.

\section{Map 1}

Brazil: quality of rural and urban agricultural occupations, by state, 2014

A. Rural agricultural jobs

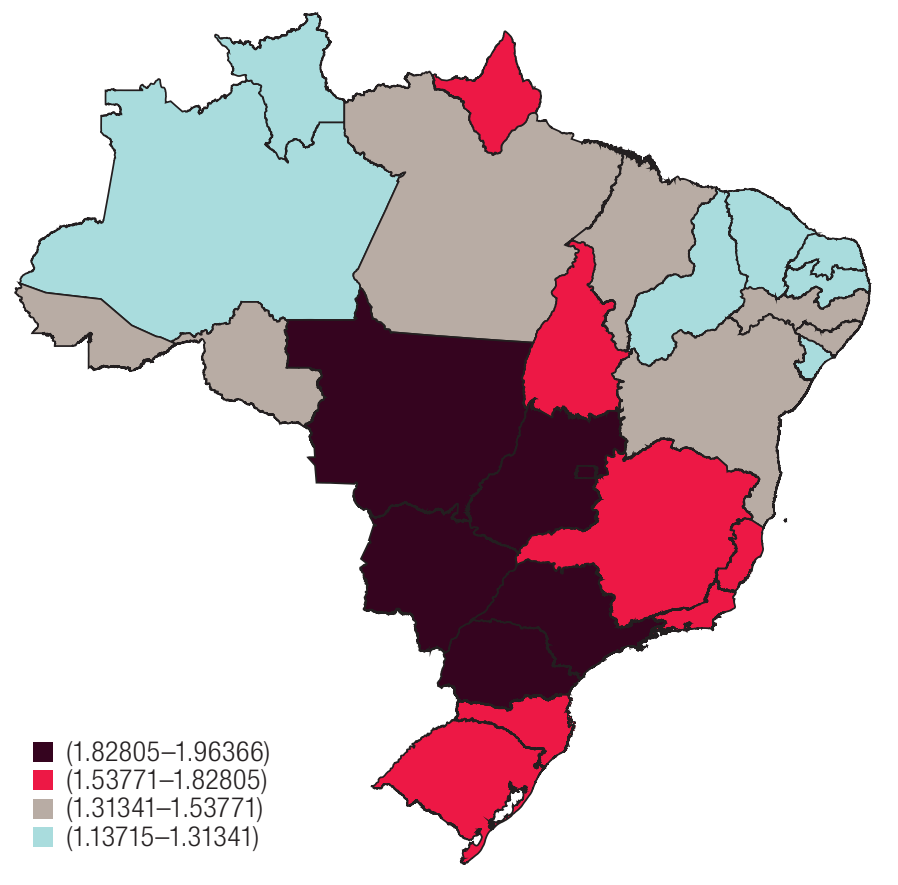


Map 1 (concluded)

B. Urban agricultural jobs

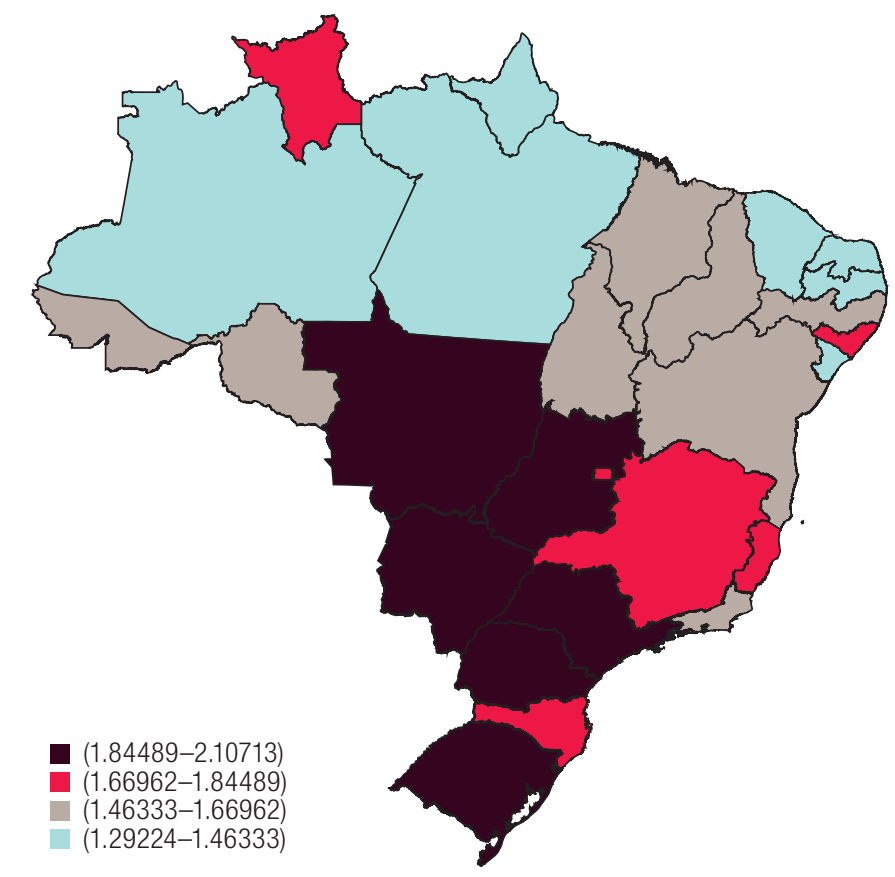

Source: Prepared by the authors.

However, although the Centre-West Region stands out in terms of agricultural employment, its non-agricultural employment is of lower quality than in other regions of Brazil. Nonetheless, the quality of non-agricultural employment is still superior to agricultural employment owing to its conditions and characteristics. The states of the South and South-East Regions that display greater urban-industrial development are the areas where conditions of urban non-agricultural employment are also the best, as can be seen in map 2.

Although the North-East Region shows some progress since the start of the series (see table 4), its results are inferior to those of the other regions of the country and generally below the national average. The lesser modernization of economic activities, both agricultural and non-agricultural, produces a relatively precarious context for labour market development and sophistication, which is reflected in the lower job quality in this region, as illustrated in maps 1 and 2. Even in the states of the North-East where economic activity is more intense, for example in Bahia, the level of labour market development is not very high. As a result, the region lacks mechanisms to foster an improvement in employment practices, since even urban non-agricultural employment, where the best quality standards are generally concentrated, is not superior to that of the other regions. 
Map 2

Brazil: quality of rural and urban non-agricultural occupations, by state, 2014

A. Rural non-agricultural jobs

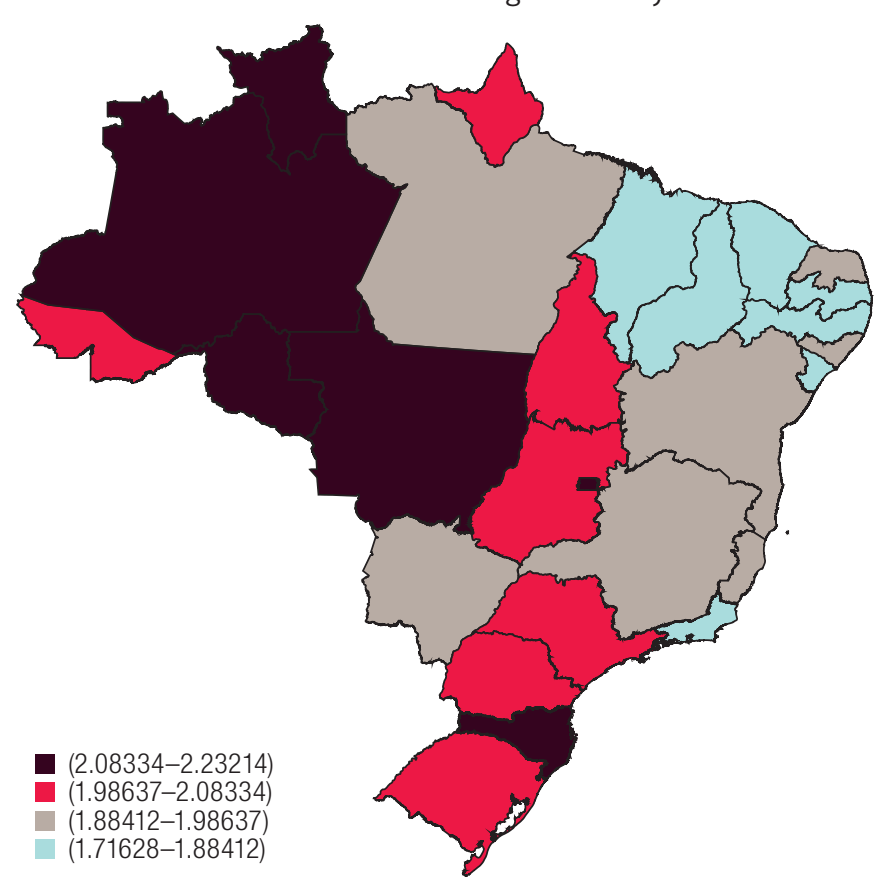

B. Urban non-agricultural jobs

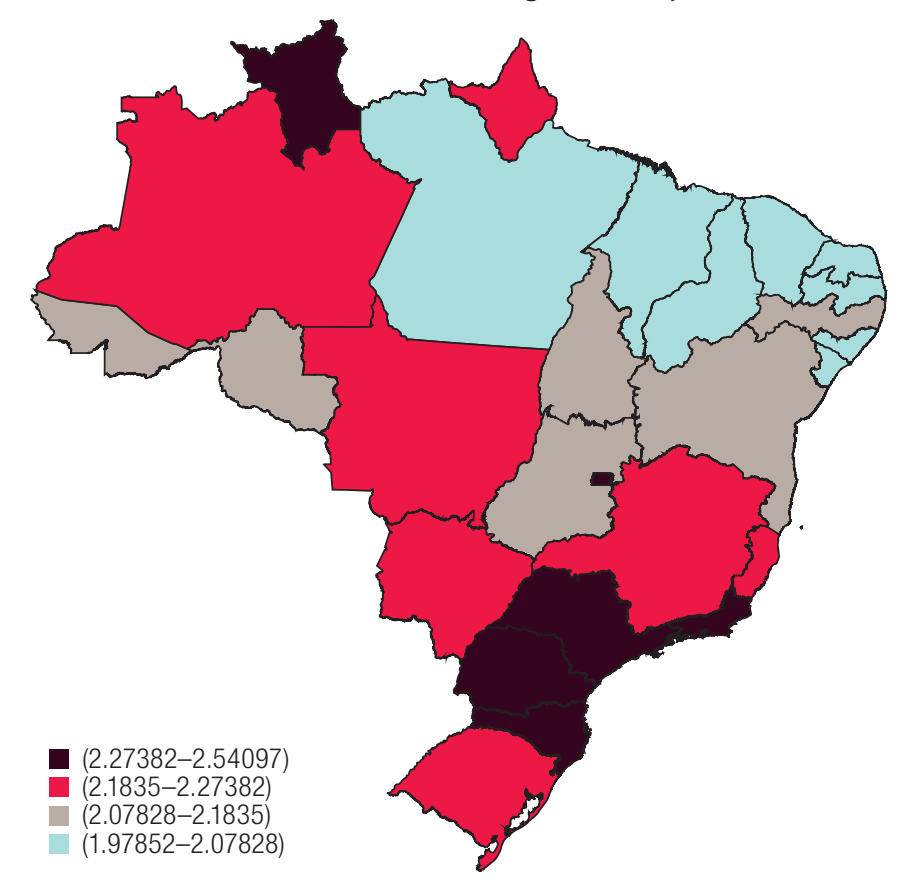

Source: Prepared by the authors. 
Table 4

Brazil: quality of employment index by category and subnational units

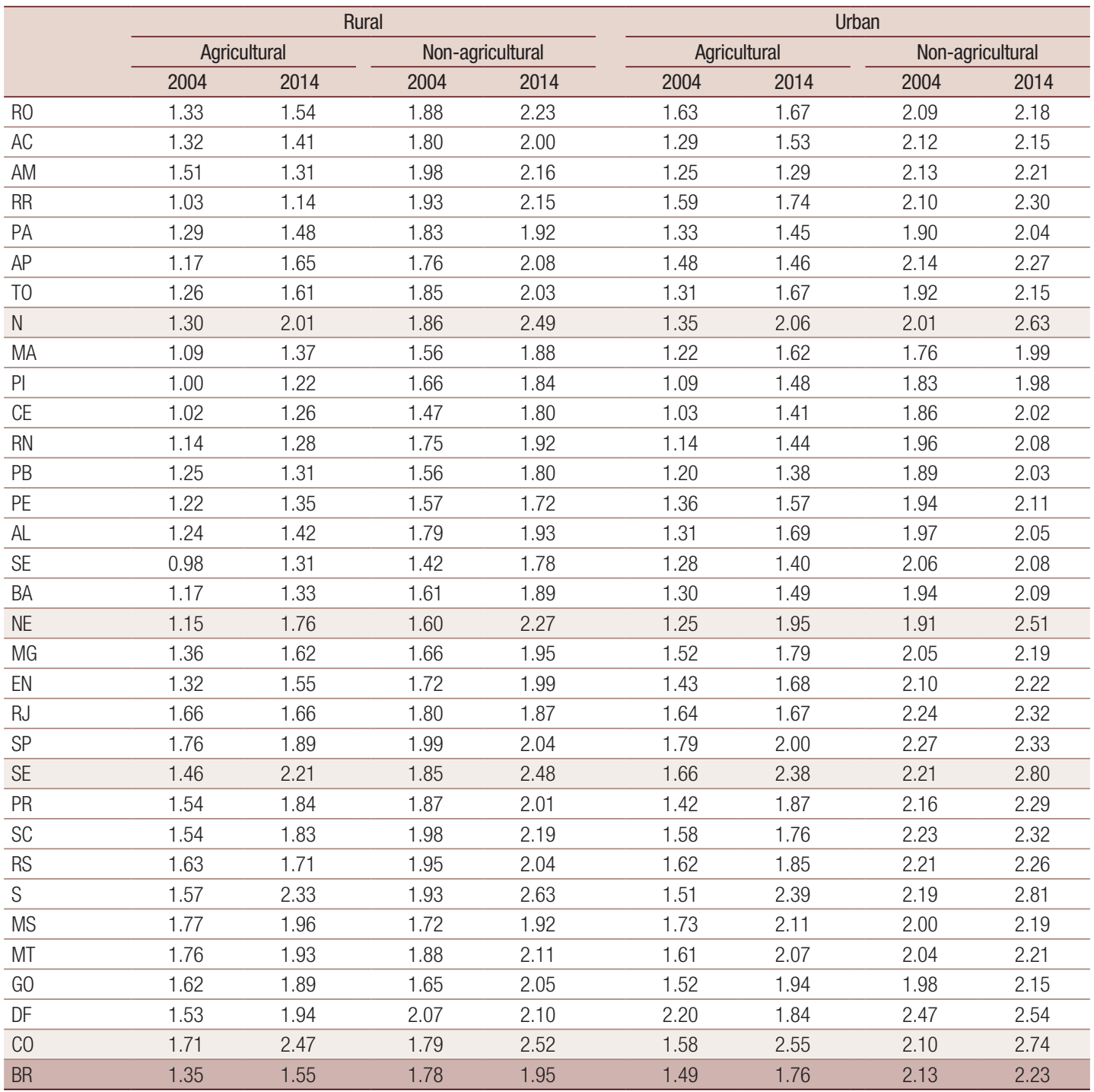

Source: Prepared by the authors.

The best quality standards in agricultural employment are mainly seen in regions where agriculture is more highly developed. Thus, traditional agricultural activities, which are more common in the North-East Region, define a scenario in which employment relations are more precarious than those of the modern agriculture practised in the centre-south of the country. The large grain-producing states register the best quality of employment. Consequently, the agro-export system of the centresouth stands out not only for its production capacity, but also because it offers better employment practices than those that characterize essentially agricultural and more traditional occupations.

The reduction in agricultural employment did not entail a significant decline in Brazil's rural population in the decade of 2000. This is because people previously employed in agricultural activities have sought jobs with better conditions in the non-agricultural labour market, but without leaving the rural area (see table 3). Thus, rural non-agricultural employment acts as a "buffer" between lower-quality agricultural employment in rural areas and higher-quality non-agricultural employment in urban areas, with quality levels between the two (see table 4). 
The regional analysis shows that the states of the South Region, together with São Paulo, Rio de Janeiro and the Federal District, display the best quality levels, especially in the case of urban non-agricultural employment (see map 2B). In this category, some states in northern Brazil also display a high quality index, even though they are less economically dynamic and do not have a developed urban structure. In these cases, which are areas of lower population density, the need to attract workers from other parts of the country results in incentives being offered. This, in turn, is reflected in a better relative quality of employment, as suggested by the results reported by Freguglia, Gonçalves and Da Silva (2014). This also seems to be the case for rural non-agricultural employment (see map 2A), where the Centre-South Region stands out. Once again, the development level of non-agricultural activities in these states allow for a better "blending" of non-agricultural activities with the rural environment, since the dynamics and magnitude of the economic activities developed there produce more advanced employment relations than in the other areas of the country.

The results reported thus far reveal a labour market that is highly heterogeneous and asymmetric, in both sectoral and spatial terms. The centre-south economic complex has a much more sophisticated labour structure, in terms of quality, than the North-East and North Regions, where progress has been stronger but is still insufficient to catch up with the other Brazilian regions.

Brazil's rapid march towards industrial capitalism reinforced the characteristics of an extremely asymmetric and disconnected labour market. In the early 1960s, these paradigms induced heavy migration from the countryside to the city, culminating in the perception of rural areas that were emptying. The new configuration of the agricultural and non-agricultural labour market, characterized by heterogeneity, promotes a different migratory dynamic, intersectoral rather than spatial as in the past (Fajardo, 2008; Priori and others, 2012).

The results illustrated in maps 1 and 2 also show that the regions less closely connected to the Brazilian agribusiness system have a group of workers subject to more precarious job quality (both in spatial and in sectoral terms). This is the result of unemployment and chronic underemployment as specific phenomena of the economic-social composition of these regions and of Brazil itself. In the past, this fuelled intense migratory flows from the rural areas of these regions to the urban areas of the large agribusiness complex of the centre-south, and which now continues in the shift from the agricultural to the non-agricultural sector. This mixed migratory flow is inherent to the dual economic growth model that has characterized Brazil's development path. Many workers are immersed in a traditional and precarious low-productivity production system. In the poorer regions, this motivates them to move to the more modern region or sector, where labour productivity is higher and, therefore, the quality of employment is better. Other features of this scenario include a lack of opportunities for the rural population in the poorer regions to access land; the resistance of the large-estate (latifundio) sector to the formation of a campesino population; and the more backward forms of capitalist management, which have repercussions on the labour market.

Throughout the period under review, there were significant improvements in job quality, especially in the lowest-quality regions. However, as the data in table 4 show, significant regional and sectoral heterogeneities still persist. For example, the quality of employment in the North and North-East Regions is relatively worse than in the agribusiness complex in the centre-south of the country; and the quality of agricultural employment is inferior to that of non-agricultural employment.

\section{Quality of employment index: empirical results}

This section reports and analyses the results produced by the econometric models presented in the section on methodological issues, which relate the job quality index for the four groups studied to a set of variables that synthesize some of the factors that determine the structure of the Brazilian labour 
market. The section is organized as an interpretation of four tables (tables 5, 6, 7 and 8) that report the estimations of the four equations proposed. The interpretation starts with data on rural agricultural employment; then this is followed by urban agricultural, rural non-agricultural and, lastly, urban non-agricultural employment.

Table 5

Estimation results of the selected models for the rural agricultural labour market

\begin{tabular}{|c|c|c|c|c|c|c|c|c|c|c|c|c|}
\hline \multirow[t]{2}{*}{ Variables } & \multicolumn{3}{|c|}{$\begin{array}{l}\text { Ordinary least squares } \\
\qquad[\mathrm{A}]\end{array}$} & \multicolumn{3}{|c|}{$\begin{array}{l}\text { Fixed-effects panel } \\
\text { [B] }\end{array}$} & \multicolumn{3}{|c|}{$\begin{array}{l}\text { Instrumental variables } \\
\text { regression } \\
\text { [C] }\end{array}$} & \multicolumn{3}{|c|}{$\begin{array}{l}\text { Generalized method } \\
\text { of moments } \\
\text { [D] }\end{array}$} \\
\hline & Coeff & $t$ & $p>|t|$ & Coeff & $\mathrm{t}$ & $p>|t|$ & Coeff & $z$ & $p>|| z \mid$ & Coeff & $z$ & $p>\| z \mid$ \\
\hline $\begin{array}{l}\text { Quality of } \\
\text { employment index }\end{array}$ & 0.721 & 12.39 & 0.000 & 0.140 & 1.98 & 0.049 & 0.494 & 4.28 & 0.000 & 0.494 & 4.28 & 0.000 \\
\hline $\begin{array}{l}\text { Agricultural } \\
\text { value-added }\end{array}$ & 0.006 & 0.87 & 0.387 & -0.046 & -1.95 & 0.053 & 0.104 & 2.52 & 0.012 & 0.104 & 2.52 & 0.012 \\
\hline $\begin{array}{l}\text { Non-agricultural } \\
\text { value-added }\end{array}$ & -0.009 & -1.50 & 0.135 & 0.139 & 3.43 & 0.001 & -0.082 & -2.34 & 0.019 & -0.082 & -2.34 & 0.019 \\
\hline Income & 0.047 & 3.05 & 0.003 & 0.034 & 1.51 & 0.132 & 0.095 & 2.80 & 0.005 & 0.095 & 2.80 & 0.005 \\
\hline Inequality & 0.090 & 0.93 & 0.353 & -0.050 & -0.42 & 0.676 & 0.208 & 0.55 & 0.583 & 0.208 & 0.55 & 0.583 \\
\hline Education & 0.028 & 1.82 & 0.071 & -0.127 & -2.52 & 0.013 & 0.093 & 2.12 & 0.034 & 0.093 & 2.12 & 0.034 \\
\hline \multirow[t]{10}{*}{ Statistical tests } & \multicolumn{3}{|c|}{$F(6 ; 210)=1860.37$} & \multicolumn{3}{|c|}{$F(6 ; 183)=16.06$} & \multicolumn{3}{|c|}{$F(6 ; 7)=2071.99$} & \multicolumn{3}{|c|}{ Wald $(6)=14546.24$} \\
\hline & \multicolumn{3}{|c|}{ Prob $>F=0.000$} & \multicolumn{3}{|c|}{ Prob $>F=0.000$} & \multicolumn{3}{|c|}{ Prob $>F=0.000$} & \multicolumn{3}{|c|}{ Prob $>$ chi2 $=0.000$} \\
\hline & \multicolumn{3}{|c|}{$\begin{array}{c}\text { Number of } \\
\text { observations }=216\end{array}$} & \multicolumn{3}{|c|}{$\begin{array}{c}\text { Number of } \\
\text { observations }=216\end{array}$} & \multicolumn{3}{|c|}{$\begin{array}{c}\text { Number of } \\
\text { observations }=216\end{array}$} & \multicolumn{3}{|c|}{$\begin{array}{c}\text { Number of } \\
\text { observations = } 216\end{array}$} \\
\hline & \multicolumn{3}{|c|}{ Adjusted $R^{2}=0.970$} & \multicolumn{3}{|c|}{$\mathrm{R}^{2}$ (within) $=0.3449$} & \multicolumn{3}{|c|}{$\mathrm{R}^{2}$ (uncentred) $=0.93$} & \\
\hline & & & & \multicolumn{3}{|c|}{ Groups $=27$} & \multicolumn{3}{|c|}{ Groups $=8$} & \multicolumn{2}{|c|}{ Groups $=27$} & \\
\hline & & & & & & & \multicolumn{3}{|c|}{ Kleibergen $=0.0158$} & \multicolumn{3}{|c|}{ Instruments $=7$} \\
\hline & \multicolumn{9}{|c|}{ HO: Absence of first-order autocorrelation } & \multicolumn{3}{|c|}{0.039} \\
\hline & \multicolumn{9}{|c|}{ HO: Absence of second-order autocorrelation } & \multicolumn{3}{|c|}{0.260} \\
\hline & \multicolumn{9}{|c|}{ Sargan test } & \multicolumn{3}{|c|}{0.608} \\
\hline & \multicolumn{9}{|c|}{ Hansen test } & & 0.621 & \\
\hline
\end{tabular}

Source: Prepared by the authors.

Table 6

Estimation results of the selected models for the urban agricultural labour market

\begin{tabular}{|c|c|c|c|c|c|c|c|c|c|c|c|c|}
\hline \multirow[t]{2}{*}{ Variables } & \multicolumn{3}{|c|}{$\begin{array}{l}\text { Ordinary least squares } \\
\qquad[\mathrm{A}]\end{array}$} & \multicolumn{3}{|c|}{$\begin{array}{l}\text { Fixed-effects panel } \\
\qquad[\mathrm{B}]\end{array}$} & \multicolumn{3}{|c|}{$\begin{array}{l}\text { Instrumental variables } \\
\text { regression } \\
{[\mathrm{C}]} \\
\end{array}$} & \multicolumn{3}{|c|}{$\begin{array}{c}\text { Generalized method } \\
\text { of moments } \\
\text { [D] }\end{array}$} \\
\hline & Coeff & $t$ & $p>|t|$ & Coeff & $t$ & $p>|t|$ & Coeff & $z$ & $\mathrm{p}>\||z|$ & Coeff & $z$ & $p>\| z \mid$ \\
\hline $\begin{array}{l}\text { Quality of } \\
\text { employment index }\end{array}$ & 0.599 & 8.7 & 0.000 & 0.109 & 1.5 & 0.137 & 0.562 & 7.4 & 0.000 & 0.562 & 7.4 & 0.000 \\
\hline $\begin{array}{l}\text { Agricultural } \\
\text { value-added }\end{array}$ & 0.018 & 2.5 & 0.013 & 0.016 & 0.6 & 0.551 & 0.027 & 3.1 & 0.002 & 0.027 & 3.1 & 0.002 \\
\hline $\begin{array}{l}\text { Non-agricultural } \\
\text { value-added }\end{array}$ & -0.005 & -0.9 & 0.392 & 0.072 & 1.5 & 0.126 & -0.003 & -0.9 & 0.348 & -0.003 & -0.9 & 0.348 \\
\hline Income & 0.032 & 2.6 & 0.010 & 0.042 & 2.2 & 0.031 & 0.066 & 4.9 & 0.000 & 0.066 & 4.9 & 0.000 \\
\hline Inequality & -0.028 & -0.3 & 0.773 & -0.279 & -2.0 & 0.045 & 0.452 & 2.5 & 0.011 & 0.452 & 2.5 & 0.011 \\
\hline Education & 0.079 & 4.0 & 0.000 & -0.044 & -0.8 & 0.454 & 0.048 & 2.4 & 0.016 & 0.048 & 2.4 & 0.016 \\
\hline \multirow[t]{10}{*}{ Statistical tests } & \multicolumn{3}{|c|}{$F(6 ; 210)=2050.09$} & \multicolumn{3}{|c|}{$F(6 ; 183)=26.08$} & \multicolumn{3}{|c|}{$F(6 ; 26)=1039.96$} & \multicolumn{3}{|c|}{ Wald $(6)=6634.06$} \\
\hline & \multicolumn{3}{|c|}{ Prob $>F=0.000$} & \multicolumn{3}{|c|}{ Prob $>F=0.000$} & \multicolumn{3}{|c|}{ Prob $>F=0.000$} & \multicolumn{3}{|c|}{ Prob $>$ chi2 $=0.000$} \\
\hline & \multicolumn{3}{|c|}{$\begin{array}{c}\text { Number of } \\
\text { observations }=216\end{array}$} & \multicolumn{3}{|c|}{$\begin{array}{c}\text { Number of } \\
\text { observations = } 216\end{array}$} & \multicolumn{3}{|c|}{$\begin{array}{c}\text { Number of } \\
\text { observations = } 216\end{array}$} & \multicolumn{3}{|c|}{$\begin{array}{c}\text { Number of } \\
\text { observations }=216\end{array}$} \\
\hline & \multicolumn{3}{|c|}{ Adjusted $R^{2}=0.9696$} & \multicolumn{3}{|c|}{$\mathrm{R}^{2}$ (within) $=0.4609$} & \multicolumn{3}{|c|}{$\mathrm{R}^{2}$ (uncentred) $=0.97$} & & & \\
\hline & & & & \multicolumn{3}{|c|}{ Groups $=27$} & \multicolumn{3}{|c|}{ Groups $=27$} & \multicolumn{3}{|c|}{ Groups $=27$} \\
\hline & & & & & & & \multicolumn{3}{|c|}{ Kleibergen $=0.0071$} & \multicolumn{3}{|c|}{ Instruments $=7$} \\
\hline & \multicolumn{9}{|c|}{ HO: Absence of first-order autocorrelation } & \multicolumn{3}{|c|}{0.001} \\
\hline & \multicolumn{9}{|c|}{ HO: Absence of second-order autocorrelation } & \multicolumn{3}{|c|}{0.523} \\
\hline & \multicolumn{9}{|c|}{ Sargan test } & \multicolumn{3}{|c|}{0.394} \\
\hline & \multicolumn{9}{|c|}{ Hansen test } & \multicolumn{3}{|c|}{0.386} \\
\hline
\end{tabular}

Source: Prepared by the authors. 
Table 7

Estimation results of selected models for the rural non-agricultural labour market

\begin{tabular}{|c|c|c|c|c|c|c|c|c|c|c|c|c|}
\hline \multirow[t]{2}{*}{ Variables } & \multicolumn{3}{|c|}{$\begin{array}{l}\text { Ordinary least squares } \\
\qquad[\mathrm{A}]\end{array}$} & \multicolumn{3}{|c|}{$\begin{array}{l}\text { Fixed-effects panel } \\
\text { [B] }\end{array}$} & \multicolumn{3}{|c|}{$\begin{array}{l}\text { Instrumental variables } \\
\text { regression } \\
{[\mathrm{C}]}\end{array}$} & \multicolumn{3}{|c|}{$\begin{array}{l}\text { Generalized method } \\
\text { of moments } \\
\text { [D] }\end{array}$} \\
\hline & Coeff & $t$ & $p>|t|$ & Coeff & $\mathrm{t}$ & $p>|t|$ & Coeff & $z$ & $p>\| z \mid$ & Coeff & $z$ & $p>\| z \mid$ \\
\hline $\begin{array}{l}\text { Quality of } \\
\text { employment index }\end{array}$ & 0.465 & 8.0 & 0.000 & 0.071 & 1.2 & 0.253 & 0.405 & 5.0 & 0.000 & 0.405 & 5.0 & 0.000 \\
\hline $\begin{array}{l}\text { Agricultural } \\
\text { value-added }\end{array}$ & 0.008 & 1.8 & 0.082 & 0.003 & 0.2 & 0.836 & 0.011 & 1.3 & 0.206 & 0.011 & 1.3 & 0.206 \\
\hline $\begin{array}{l}\text { Non-agricultural } \\
\text { value-added }\end{array}$ & -0.011 & -3.3 & 0.001 & -0.064 & -2.5 & 0.014 & -0.015 & -2.1 & 0.040 & -0.015 & -2.1 & 0.040 \\
\hline Income & 0.077 & 8.0 & 0.000 & 0.167 & 8.5 & 0.000 & 0.052 & 6.3 & 0.000 & 0.052 & 6.3 & 0.000 \\
\hline Inequality & 0.081 & 1.3 & 0.195 & 0.133 & 1.9 & 0.065 & -0.292 & -2.2 & 0.029 & -0.292 & -2.2 & 0.029 \\
\hline Education & 0.029 & 3.6 & 0.000 & 0.012 & 0.4 & 0.687 & 0.053 & 2.9 & 0.003 & 0.053 & 2.9 & 0.003 \\
\hline \multirow[t]{10}{*}{ Statistical tests } & \multicolumn{3}{|c|}{$F(6 ; 210)=12234.51$} & \multicolumn{3}{|c|}{$F(6 ; 183)=46.10$} & \multicolumn{3}{|c|}{$F(6 ; 7)=3268.60$} & \multicolumn{3}{|c|}{ Wald(6) = 22946.87} \\
\hline & \multicolumn{3}{|c|}{ Prob $>F=0.000$} & \multicolumn{3}{|c|}{ Prob $>F=0.000$} & \multicolumn{3}{|c|}{ Prob $>F=0.000$} & \multicolumn{3}{|c|}{ Prob > chi2 $=0.000$} \\
\hline & \multicolumn{3}{|c|}{$\begin{array}{c}\text { Number of } \\
\text { observations = } 216\end{array}$} & \multicolumn{3}{|c|}{$\begin{array}{c}\text { Number of } \\
\text { observations = } 216\end{array}$} & \multicolumn{3}{|c|}{$\begin{array}{c}\text { Number of } \\
\text { observations = } 216\end{array}$} & \multicolumn{3}{|c|}{$\begin{array}{c}\text { Number of } \\
\text { observations }=216\end{array}$} \\
\hline & \multicolumn{3}{|c|}{ Adjusted $R^{2}=0.9957$} & \multicolumn{3}{|c|}{$R^{2}$ (within) $=0.6018$} & \multicolumn{3}{|c|}{$\mathrm{R}^{2}$ (uncentred) $=0.995$} & \\
\hline & & & & \multicolumn{3}{|c|}{ Groups $=27$} & \multicolumn{3}{|c|}{ Groups $=8$} & \multicolumn{2}{|c|}{ Groups $=27$} & \\
\hline & & & & & & & \multicolumn{3}{|c|}{ Kleibergen $=0.0033$} & \multicolumn{3}{|c|}{ Instruments = 7} \\
\hline & \multicolumn{9}{|c|}{ HO: Absence of first-order autocorrelation } & \multicolumn{3}{|c|}{0.004} \\
\hline & \multicolumn{9}{|c|}{ HO: Absence of second-order autocorrelation } & \multicolumn{3}{|c|}{0.561} \\
\hline & \multicolumn{9}{|c|}{ Sargan test } & \multicolumn{3}{|c|}{0.819} \\
\hline & \multicolumn{9}{|c|}{ Hansen test } & & 0.56 & \\
\hline
\end{tabular}

Source: Prepared by the authors.

Table 8

Estimation results of selected models for the urban non-agricultural labour market

\begin{tabular}{|c|c|c|c|c|c|c|c|c|c|c|c|c|}
\hline \multirow[t]{2}{*}{ Variables } & \multicolumn{3}{|c|}{$\begin{array}{l}\text { Ordinary least squares } \\
\qquad[\mathrm{A}]\end{array}$} & \multicolumn{3}{|c|}{$\begin{array}{l}\text { Fixed-effects panel } \\
\text { [B] }\end{array}$} & \multicolumn{3}{|c|}{$\begin{array}{l}\text { Instrumental variables } \\
\text { regression } \\
{[\mathrm{C}]}\end{array}$} & \multicolumn{3}{|c|}{$\begin{array}{l}\text { Generalized method } \\
\text { of moments } \\
\text { [D] }\end{array}$} \\
\hline & Coeff & $T$ & $p>|t|$ & Coeff & $t$ & $p>|t|$ & Coeff & $z$ & $p>\||z|$ & Coeff & $z$ & $p>\| z \mid$ \\
\hline $\begin{array}{l}\text { Quality of } \\
\text { employment index }\end{array}$ & 0.849 & 29.6 & 0.000 & 0.407 & 8.0 & 0.000 & 0.834 & 15.3 & 0.000 & 0.834 & 15.3 & 0.000 \\
\hline $\begin{array}{l}\text { Agricultural } \\
\text { value-added }\end{array}$ & -0.001 & -0.8 & 0.415 & 0.004 & 0.8 & 0.406 & -0.003 & -1.3 & 0.196 & -0.003 & -1.3 & 0.196 \\
\hline $\begin{array}{l}\text { Non-agricultural } \\
\text { value-added }\end{array}$ & 0.001 & 0.5 & 0.649 & -0.079 & -4.6 & 0.000 & 0.002 & 1.5 & 0.138 & 0.002 & 1.5 & 0.138 \\
\hline Income & 0.020 & 5.5 & 0.000 & 0.105 & 5.3 & 0.000 & 0.018 & 3.0 & 0.002 & 0.018 & 3.0 & 0.002 \\
\hline Inequality & 0.012 & 0.8 & 0.454 & -0.080 & -2.8 & 0.007 & -0.028 & -0.7 & 0.477 & -0.028 & -0.7 & 0.477 \\
\hline Education & 0.0 & 2.3 & 0.023 & 0.051 & 5.2 & 0.000 & 0.007 & 1.6 & 0.100 & 0.007 & 1.6 & 0.100 \\
\hline \multirow[t]{10}{*}{ Statistical tests } & \multicolumn{3}{|c|}{$F(6 ; 210)=99999$} & \multicolumn{3}{|c|}{$F(6 ; 183)=167.93$} & \multicolumn{3}{|c|}{$F(6 ; 7)=64182.17$} & \multicolumn{3}{|c|}{ Wald $(6)=450585$} \\
\hline & \multicolumn{3}{|c|}{ Prob $>F=0.000$} & \multicolumn{3}{|c|}{ Prob $>F=0.000$} & \multicolumn{3}{|c|}{ Prob $>F=0.000$} & \multicolumn{3}{|c|}{ Prob $>$ chi $2=0.00$} \\
\hline & \multicolumn{3}{|c|}{$\begin{array}{c}\text { Number of } \\
\text { observations }=216\end{array}$} & \multicolumn{3}{|c|}{$\begin{array}{c}\text { Number of } \\
\text { observations }=216\end{array}$} & \multicolumn{3}{|c|}{$\begin{array}{c}\text { Number of } \\
\text { observations }=216\end{array}$} & \multicolumn{3}{|c|}{$\begin{array}{c}\text { Number of } \\
\text { observations = } 216\end{array}$} \\
\hline & \multicolumn{3}{|c|}{ Adjusted $R^{2}=0.9997$} & \multicolumn{3}{|c|}{$\mathrm{R}^{2}$ (within) $=0.8463$} & \multicolumn{3}{|c|}{$\mathrm{R}^{2}$ (uncentred) $=0.9997$} & & & \\
\hline & & & & \multicolumn{3}{|c|}{ Groups $=27$} & \multicolumn{3}{|c|}{ Groups $=8$} & \multicolumn{3}{|c|}{ Groups $=27$} \\
\hline & & & & & & & \multicolumn{3}{|c|}{ Kleibergen $=0.0000$} & \multicolumn{3}{|c|}{ Instruments $=9$} \\
\hline & \multicolumn{9}{|c|}{ HO: Absence of first-order autocorrelation } & \multicolumn{3}{|c|}{0.000} \\
\hline & \multicolumn{9}{|c|}{$\mathrm{HO}$ : Absence of second-order autocorrelation } & \multicolumn{3}{|c|}{0.979} \\
\hline & \multicolumn{9}{|c|}{ Sargan test } & \multicolumn{3}{|c|}{0.189} \\
\hline & \multicolumn{9}{|c|}{ Hansen test } & \multicolumn{3}{|c|}{0.998} \\
\hline
\end{tabular}

Source: Prepared by the authors. 
Column [A] of each table reports the result of the OLS estimations; and column [B] shows the estimations obtained using the fixed-effects panel method, which is more efficient than the random-effects method, according to the Hausman test in all four of the models estimated. Column [C] presents the instrumental variables model, used to evaluate the possibility of underidentification. Lastly, column [D] presents the parameter estimates obtained through system-GMM. It should be noted that [C] and [D] are essentially the same model. As noted above, system-GMM is the result of an extension of the original Arellano and Bond (1991) estimator, proposed by Arellano and Bover (1995) and developed further by Blundell and Bond (1998).

As can be seen in column [A] of each table, the estimated coefficients of the variable "Quality of employment lagged by one period" obtained through OLS are, in fact, higher than those shown in column $[\mathrm{B}]$ for this same variable using the fixed-effects panel data method. If the instruments used are appropriate, the coefficient on this variable estimated by GMM should lie between the coefficients estimated by the two previous methods. This is precisely what column [D] confirms. With this characteristic satisfied, the bias caused by the presence of endogenous variables on the right side of the regression and the unobservable fixed effects was corrected by GMM.

Thus, among the models presented in tables 5, 6, 7 and 8, those indicated in column [D] of each table were always chosen. The tests performed in system-GMM show that the statistical properties of the models are acceptable. The Hansen test, which indicates whether the instruments used are valid, and the Sargan test, which verifies the validity of the additional instruments required by system-GMM, are satisfied for the four models estimated, as can be seen in tables 5, 6, 7 and 8. It should also be noted that the null hypothesis of the Kleibergen and Paap (2006) underidentification test is rejected, indicating that the model contained in column [C] is not underidentified. ${ }^{1}$ Note also that while the estimations of [C] and [D] are different, they are basically the same model, which indicates that [D] is also not underidentified.

Lastly, the Arellano and Bond (1991) statistical tests are also included to evaluate the existence of both first- and second-order autocorrelation. The absence of the latter is essential for the consistency of the GMM estimator. The test confirms that the hypothesis of first-order autocorrelation is not rejected, but second-order autocorrelation is rejected in all four models presented. This is as expected and in keeping with the instructions in the panel data literature. Accordingly, the models are rated as acceptable.

An initial finding is that the coefficient of the variable "Agricultural value-added" is not statistically significant for non-agricultural employment, whether urban or rural. This represents a significant feature of non-agricultural labour market behaviour in the groups studied. In principle, the expansion of agricultural production does not cause structural changes in the non-agricultural labour market. What is captured here is the weak linkage between agricultural output and the overall labour market, since, on average, the sector accounted for just $5.7 \%$ of the total output of the Brazilian economy in the reference period. Although the growth of agricultural production may also stimulate non-agricultural production and, hence, boost employment, a simple increase in the number of workers does not imply an improvement in job quality. Moreover, the coefficient of the variable "Non-agricultural value-added" is not significant for urban non-agricultural employment either. Thus, the growth of the urban non-agricultural labour market induced by the expansion of agricultural or non-agricultural production does not, per se, cause a change in existing or new employment relationships. The quality of these new hirings is, on average, similar to the job quality experienced by workers already participating in the market, without altering the sophistication structure of employment in these groups.

\footnotetext{
1 The underidentification test determines whether the equation is identified, in other words whether the excluded instruments are "relevant" in the sense of being correlated with the endogenous regressors. This is essentially the rank test of a matrix: under the null hypothesis that the equation is underidentified, the reduced-form matrix of coefficients on the excluded instruments of $\mathrm{L} 1$ has rank $=\mathrm{K} 1-1$ where $\mathrm{K} 1=$ number of endogenous regressors. Under the null hypothesis, the statistic approximates a chi-squared distribution, with $(\mathrm{L} 1-\mathrm{K} 1+1)$ degrees of freedom. Rejection of the null hypothesis indicates that the matrix has full column rank; that is, the model is identified. For further information see Kleibergen and Paap (2006).
} 
However, the variable "Agricultural value-added" is positive and statistically significant at a significance level of at least 5\%, for the agricultural employment groups - both rural (see table 5) and urban (see table 6). This means that agricultural employment responds more to the growth of agricultural production than does non-agricultural employment. Accordingly, an increase in agricultural activity has significant effects on the quality of agricultural employment.

The negative sign on non-agricultural value-added indicates that the growth of industrial and service activities is inversely related to the quality of employment for the groups in which this variable has a negative sign (rural agricultural, urban agricultural ${ }^{2}$ and rural non-agricultural employment). ${ }^{3}$ According to Balsadi and Delgrossi (2018), the population employed in agriculture is ageing progressively, and the abandonment of agricultural activities - to a greater extent by women and young people - contributes to the precariousness of this type of employment and even to some farming enterprises going out of business, as seen in some regions of Brazil. Thus, the expansion of non-agricultural production, which offers new employment opportunities to these groups, contributes to the relatively lacklustre performance of agricultural employment, with repercussions on its quality, as evidenced by the econometric models.

It is also found that labour hiring practices in non-agricultural activities are much more formal, which translates into higher income, shorter working hours and a lower incidence of child labour. Thus, as activities develop, they tend to influence agricultural labour through the sectoral migration process, as agricultural workers seek to improve their situation by engaging in activities in other sectors that offer better job quality.

The coefficient of the "Income" variable, which represents average labour income in each of Brazil's federative units, is statistically significant at a level of at least $5 \%$ and, as expected, has a positive sign for the four equations analysed. Thus, an increase in average labour income has significant effects on employment quality. This indicates that a policy of raising real wages may be important for improving the quality of employment and, above all, the profile of the workers. From this perspective, the increase in income is associated with jobs that have better labour hiring practices. It is also possible that the increase in income induces a competitive process within the labour market. Employers are encouraged to improve their hiring methods in order to obtain the workers they want; and the workers, in turn, feel less inclined to stay in precarious jobs (of lower quality), with lower income levels - at least in an environment of economic growth and declining unemployment, such as prevailed throughout most of the period analysed.

With regard to elasticities, the elasticity of employment quality with respect to income is less than unity in all cases, and so more inelastic. Nonetheless, raising the average wage in each federative unit could help reduce the differences between labour markets, both urban and rural and non-agricultural and agricultural, since the effects of an increase in state-average income are smaller in the former, as shown in the coefficients reported in tables 5, 6, 7 and 8.

The "inequality" variable, represented by the Gini index, which measures the degree of income concentration, is statistically significant and negative for rural non-agricultural employment; and negative, but not significant, for urban non-agricultural employment. Thus, the income concentration structure influences job quality in this segment of the labour market. A drop in the Gini index implies that the income level of the poorest workers converges to a higher level, with the respective repercussions in terms of job quality, since the "inequality" variable is inversely proportional to the job quality index. However, in

\footnotetext{
2 Following the line of reasoning developed in this paragraph, urban agricultural employment should be treated with caution. Although the sign of the coefficient of non-agricultural value-added is negative, like that of the other types of employment, it is weakly non-significant; so this result and the inferences based on it should be interpreted with caution.

3 Although rural non-agricultural employment is a "product" of the sectoral migration of workers from agriculture to non-agricultural activities, agriculture still seems to exert a strong influence on the labour market for these workers, as they remain spatially linked to the rural domain and, hence, to agriculture. Thus, their behaviour, when induced by non-agricultural activities, still show similarities with that of purely agricultural activities.
} 
the case of urban non-agricultural employment, the Gini index does not seem to significantly influence job quality. Thus, urban non-agricultural employment practices maintain their own dynamics, regardless of the level of income concentration.

Lastly, the "Education" variable, which represents the population that has completed at least secondary education in each state, is significant at a level of at least $10 \%$ and has a positive sign, in accordance with the expected behaviour in these models for the four equations. From this perspective, a worker's education level influences job quality positively by increasing the chances of obtaining better jobs as the level of education rises. This is consistent with the literature that considers education level as a driver of better job quality. A labour force with higher levels of schooling is associated with higherpaying jobs, greater chances of formalization and more sophisticated conditions of employment. Thus, investments in education and job skills are very effective in terms of achieving outcomes and improvements in the quality of employment, since the latter always responds robustly to the level of education.

In the case of the variable "Quality of employment lagged by one period", IQE $E_{t-1}$, the coefficient is positive and significant at a significance level of at least $5 \%$ in all four models. This indicates that job quality tends to persist from one year to the next. Past job quality tends to persist more strongly in urban non-agricultural employment. This is because, in addition to being more sophisticated than the others, this labour market displays higher levels of formalization and greater adherence to labour legislation. The logic at play here is based on worker behaviour and the dynamics of the labour market itself. In general, workers only have incentives to change their job if the conditions offered in the future job are better than in the current one - particularly in a scenario of output growth and falling unemployment, such as characterized the period analysed (the average open unemployment rate dropped from $11.48 \%$ in 2004 to $4.8 \%$ in 2014, according to IBGE data). Thus, the prevailing macroeconomic context has a major influence on the results presented here. ${ }^{4}$ It is also argued that the labour market is resistant to giving up acquired worker rights; once acquired, they are generally not lost over time. This also applies to the quality of employment, insofar as resistance is created in the case of better working conditions already acquired. This means that job quality and its influence on current employment persists.

\section{Final remarks}

This study has sought to evaluate parallel trends in the quality of employment for four groups of workers, to evaluate the asymmetries that exist between them. A specific methodology was applied to verify the factors affecting job quality for the selected groups, in order to broaden the basis for explaining the asymmetries observed.

It is well known that the recent spatial transformations, both urban and rural, have had significant effects on employment practices. Nonetheless, this study shows that the changes in question go far beyond the new rural production dynamics. Currently, the behaviour of rural employment reflects a plurality of conditioning factors that go far beyond those operating in the rural domain. Urban dynamics are also starting to be taken into account and becoming important for evaluating the trajectory of rural employment relations more accurately.

The quality of employment index proposed in this research has revealed a wide variety in employment relations in the areas studied. In general, agricultural workers endure more precarious conditions than their non-agricultural peers. Moreover, with respect to asymmetry in the labour market, it is worth noting the differences between urban and rural employment. The rural domain remains a more precarious environment than the urban one, although the differences have been diminishing over time.

\footnotetext{
4 The research findings do not capture the effects of the recent economic, social and political crisis in Brazil, which have been more intense since 2015.
} 
The subnational spaces also present a number of specific features. In general, the best working conditions and the most intense and sophisticated dynamics are found in the agro-export complex of the centre-south of Brazil. This contrasts especially with the situation in the northern part of the North-East Region, which remains disconnected from this system and displays profound differences with respect to the agribusiness complex of the centre-south. The precarious employment relations that characterize the region are evident.

Lastly, an analysis of the models presented shows that economic growth is generally reflected to a greater extent in agricultural employment. The expansion of agricultural activities has a positive influence on the quality of agricultural employment. However, the expansion of agriculture does not seem to affect the quality of non-agricultural employment significantly, even when agribusiness is intensifying in Brazil. On the other hand, the growth of non-agricultural production generally has a negative impact on the quality of agricultural employment, since it constitutes an expansion of the possibility frontier for rural workers. As shown in this article, this contributes to the ageing of the rural population employed in agricultural activities and even impairs the viability and continuity of farming enterprises.

A different dynamic prevails in the case of non-agricultural employment. Recent economic growth has either extended the pre-existing hiring modalities, without major structural changes in the nonagricultural labour markets; or else, in some cases, it has generated jobs at the base of the pyramid with worse quality indices. However, an important caveat is needed: the long-term behaviour of the labour market may respond differently than observed thus far. This is because, as economic growth moves the economy towards full employment, extending the same hiring modalities to unemployed workers becomes increasingly difficult. As economic growth proceeds, even in the long run, it is likely to bring about changes in the labour market structure. Nonetheless, the possibility of structural changes induced by full employment has been rendered more remote by the recent crisis in Brazil.

The study also showed that increasing labour income and raising the average education level of workers are important instruments, not only for improving employment quality, but also as a strategy to overcome some of the problems of the markets studied, such as heterogeneity between groups.

\section{Bibliography}

Arellano, M. and S. Bond (1991), "Some tests of specification for panel data: Monte Carlo evidence and an application to employment equations", The Review of Economic Studies, vol. 58, No. 2, April.

Arellano, M. and O. Bover (1995), "Another look at the instrumental variable estimation of error-components models", Journal of Econometrics, vol. 68, No. 1, July.

Balsadi, O. V. (2007), "Qualidade do emprego na agricultura brasileira no período 2001-2004 e suas diferenciações por culturas", Revista de Economia e Sociologia Rural, vol. 45, No. 2, April-June.

Balsadi, O. V. and J. F. G. da Silva (2008), "A polarização da qualidade do emprego na agricultura brasileira no período 1992-2004", Economia e Sociedade, vol. 17, No. 3, December.

Balsadi, O. V. and M. E. Delgrossi (2018), "Labor and employment in Brazilian Northeastern agriculture: a look at the 2004-2014 period", Revista de Economia e Sociologia Rural, vol. 56, No. 1, January-March.

Baltagi, B. H. (2009), Econometric Analysis of Panel Data, $4^{\text {th }}$ edition, Chichester, Wiley.

Blundell, R. and S. Bond (1998), "Initial conditions and moment restrictions in dynamic panel data models", Journal of Econometrics, vol. 87, No. 1, November.

Campolina, B., F. G. Silveira and L. C. de Magalhães (2009), "O mercado de trabalho rural: evolução recente, composição da renda e dimensão regional", Texto para Discussão, No. 1398, Rio de Janeiro, Institute of Applied Economic Research (IPEA).

Carneiro, M. J. (1998), "Ruralidade: novas identidades em construção", Estudos Sociedade e Agricultura, vol. 6, No. 2, October.

Da Silva, J. G. (1997), "O novo rural brasileiro", Nova Economia, vol. 7, No. 1, May. 
Do Nascimento, C. A. and others (2008), "A qualidade do emprego rural na região nordeste (2002 e 2005)", Revista da ABET, vol. 7, No. 2, December.

Dos Passos, M. M., R. Bariou and V. Dubreuil (2006), "Evolução da fronteira agrícola no centro-oeste do Mato Grosso", Geosul, vol. 21, No. 41, January-June.

Fajardo, S. (2008), "Complexo agroindustrial, modernização da agricultura e participação das cooperativas agropecuárias no estado do Paraná", Caminhos de Geografia, vol. 9, No. 27, September.

Freguglia, R. da S., E. Gonçalves and E. R. da Silva, (2014), "Composition and determinants of the skilled out-migration in the Brazilian formal labor market: a panel data analysis from 1995 to 2006", Economia, vol. 15, No. 1, March.

Kleibergen, F. and R. Paap (2006), "Generalized reduced rank tests using the singular value decomposition", Journal of Econometrics, vol. 133, No. 1, July.

Marinho, E. and J. Araujo (2010), "Pobreza e o sistema de seguridade social rural no Brasil", Revista Brasileira de Economia, vol. 64, No. 2, April-June.

Priori, A. and others (2012), História do Paraná: séculos XIX e XX, Maringá, Eduem. 